\title{
The Enterprise Multiple Investment Strategy: International Evidence
}

\author{
Christian Walkshäusl and Sebastian Lobe*
}

\begin{abstract}
The enterprise multiple (EM) predicts the cross section of international returns. The return predictability of EM is similarly pronounced in developed and emerging markets and likewise strong among small and large firms. An international portfolio of low-EM firms outperforms a portfolio of high-EM firms by about $1 \%$ per month. The EM value premium is individually significant for the majority of countries, remains largely unexplained by existing asset pricing models, is robust after controlling for comovement with the respective U.S. premium, and is highly persistent for up to 5 years after portfolio formation, making it a promising strategy for investors.
\end{abstract}

\section{Introduction}

Loughran and Wellman (2011) document a strong relation between the enterprise multiple (EM) and average returns in the United States. They find that low-EM firms earn a significant return premium over high-EM firms. The EM is a measure of relative value and calculated as the enterprise value (the value of common stocks, preferred stocks, and debt, minus cash) divided by earnings before interest, taxes, and depreciation (EBITDA).

The results of Loughran and Wellman (2011) are interesting for two reasons. First, the return difference between low-EM firms and high-EM firms is sizeable and amounts to more than 5\% per year, making the EM particularly useful for predicting future stock returns and providing profitable investment strategies. Second, though firms with low-EM characteristics are regarded as value stocks, whereas firms with high-EM characteristics are growth stocks, the identified return effect

\footnotetext{
*Walkshäusl, christian.walkshaeus1@ur.de, Center of Finance, University of Regensburg, 93053 Regensburg, Germany; Lobe (corresponding author), sebastian.lobe@maine.edu, Maine Business School, University of Maine, Orono, ME 04469. For their comments and suggestions, we thank Hendrik Bessembinder (the editor), Tim Loughran, and participants at the 2011 Value Seminar in Frankfurt, the 2013 Annual Meeting of the German Finance Association, the 2013 Conference of the Swiss Society for Financial Market Research, and seminars at Ulm University, Wissenschaftliche Hochschule Lahr Graduate School of Business and Economics, European University Viadrina, European Business School, University of Kassel, University of Paderborn, and University of Maine for their comments. We thank Narasimhan Jegadeesh (the referee) for numerous valuable comments and suggestions that shaped this paper. We thank Kenneth French and Tim Loughran for making their data publicly available. This paper won the 2011 ACATIS Value Prize for the best research paper in value investing. All errors and omissions are our responsibility. Much of this paper was written while Lobe was at the University of Regensburg, and then at the Wissenschaftliche Hochschule Lahr.
} 
is not just a manifestation of the already well-known book-to-market (BM) value premium. As the observed return pattern cannot be explained by existing asset pricing models, their findings give rise to the existence of a distinct EM value premium.

In this paper, we contribute to the literature by shedding light on the question of whether the EM value premium is just a chance result in the U.S. equity market or likewise present in markets outside the United States. As with any finding in empirical research, the anomalous EM-return relation could be the result of data snooping within the meaning of Lo and MacKinlay (1990) and therefore could be sample specific. To address this concern, we independently examine the relation between the EM and average returns in a large international sample consisting of 40 individual non-U.S. countries, drawn from developed and emerging markets, that together account for two-thirds of the recent world market capitalization. As international markets provide fresh samples, our non-U.S. investigation delivers a useful out-of-sample test on the return effect associated with the EM. Finding EM value premiums in markets outside the United States would support the U.S. evidence and may lead to a better understanding of the behavior of stock returns in relation to the EM across equity markets and better financial investment decisions.

Our study is in the tradition of a literature that examines in an international context the return predictive ability and investment performance of variables initially identified in U.S. equity markets. For instance, Heston, Rouwenhorst, and Wessels (1995) reexamine the size effect in Europe; Fama and French (1998) the BM value premium in developed markets; Rouwenhorst (1998) momentum strategies in Europe; Rouwenhorst (1999) size, BM value, and momentum premiums in emerging markets; and recently, Fama and French (2012) the same three premiums in developed markets.

Our results are easily summarized. As in the United States, the EM predicts the cross section of international returns in a sample of 40 non-U.S. equity markets. The return predictability of EM is similarly present in developed markets and emerging markets and robust across small firms and large firms, after controlling for common benchmark variables like size, BM value, and momentum. Furthermore, we confirm the existence of a sizeable EM value premium in international markets. An internationally diversified portfolio of low-EM firms outperforms a portfolio of high-EM firms by about $1 \%$ per month. The EM value premium is individually significant in the majority of investigated countries, remains largely unexplained by existing asset pricing models, is robust after controlling for comovement with the respective U.S. premium, and is highly persistent for up to 5 years after portfolio formation, yielding a promising strategy for investors. Our out-of-sample investigation strongly supports the Loughran and Wellman (2011) story and makes it unlikely that the U.S. experience is simply due to chance. Indeed, the EM value premium seems to be a global phenomenon.

The remainder of the paper is organized as follows: In Section II, we describe the international data used in our analysis. Section III evaluates the return predictability of the EM in the cross section of international returns. In Section IV, we investigate the existence of EM value premiums in international markets, their robustness to common return factors, their comovement with the respective 
U.S. premium, and the persistence of the EM strategy over longer horizons. Section V reports further robustness tests on the EM-return relation, and Section VI concludes.

\section{Data and Variables}

\section{A. Data}

Using Datastream International, in our non-U.S. sample we study monthly total returns (i.e., including dividends) from 40 countries. ${ }^{1}$ These data include surviving and nonsurviving firms that appear on Datastream at any time in the sample period. Thus, no survivor bias is present in our analysis. All returns are denominated in U.S. dollars, and we calculate excess returns by subtracting the 1-month U.S. Treasury bill rate. ${ }^{2}$ Firm-level data are from Worldscope International. The sample period is July 1981 through June 2010 (henceforth 1981 to 2010), yielding 348 monthly observations. The start dates vary across countries due to the availability of data on Datastream. Although stock return data for some countries are available earlier than 1981, accounting information from Worldscope is not available for calendar years before 1980. Since the EM is based on lagged accounting data, we have to choose 1981 as the earliest possible start date for our study.

We restrict our data set to common stocks, which are listed on the major stock exchange(s) in each country. ${ }^{3}$ A cross-listed stock is included only in its home market. ${ }^{4}$ As common in empirical asset pricing studies, financial firms with Standard Industrial Classification (SIC) codes between 6000 and 6999 are excluded. In addition, we do not use firms with negative book equity or negative EBITDA throughout the paper to be consistent with Loughran and Wellman (2011). Mitigating the impact of outliers, we winsorize all firm-level variables at the $0.5 \%$ and $99.5 \%$ percentile levels. ${ }^{5}$ However, we do not winsorize return data, as investors are interested in average returns. Excluding extreme returns would tend to understate average returns due to the positive skewness in returns. Instead, we follow Ang, Hodrick, Xing, and Zhang (2009) and exclude very small firms by eliminating the $5 \%$ of firms with the lowest market capitalization in each country at the variable measurement date or portfolio formation date. This ensures that our conclusions are not driven by tiny or illiquid stocks. ${ }^{6}$

In order to draw meaningful inferences, especially from the analysis of individual markets, we need a reasonable number of stocks. Therefore, we require

\footnotetext{
${ }^{1}$ There are other sources for international data (i.e., Global Vantage and Morgan Stanley Capital International (MSCI) Indices); however, the coverage of these databases is not nearly as extensive as in Datastream. Global Vantage goes back only to 1993, and the target market representation of the MSCI stock universe is only $85 \%$ coverage, thus leaving out many small stocks in a country.

${ }^{2}$ Our inferences do not change when using local currencies in our country-level analyses.

${ }^{3}$ This means preferred shares, investment trusts, and depository receipts are excluded.

${ }^{4}$ In countries with multiple share classes, we select the most representative share class in terms of liquidity, ordinary voting rights, and accessibility to foreign investment.

${ }^{5}$ The decision to winsorize in contrast to trim extreme observations does not affect the paper's general findings.

${ }^{6}$ As shown by Ince and Porter (2006), possible data errors in Datastream are primarily concentrated among microcaps or stocks with very low prices.
} 
each country to have at least 30 stocks in any month after the inclusion in the sample, and each country must have a return history of at least 5 years. Taking into account these specifications, our final sample contains in total 2,272,978 firmmonth observations during the 1981-2010 time period.

Table 1 presents summary statistics for the resulting non-U.S. sample. The table lists the countries included in our study along with the major exchange(s) from which the stocks are taken, the typical fiscal year end, the start year of returns, and further market characteristics. Japan represents the largest market in our sample, accounting on average for 1,324 firms and $24.2 \%$ of total market equity. The second largest market is the United Kingdom, which has an average of 848 firms and $10.3 \%$ of total market equity. The rest of the countries are typically smaller in terms of firms and total market capitalization.

TABLE 1

Characteristics of the Country Samples

Table 1 presents summary statistics for the 40 individual countries in our non-U.S. sample. The table reports the name(s) of the major exchange(s), the typical fiscal year end, and the start year of returns for each country. The sample for each country begins in July of the year stated and ends in June 2010. The table also provides for each country the average number of firms in the sample and each country's average percentage weight in terms of total market equity. The grouping in developed and emerging markets resembles the MSCI market classification.

\begin{tabular}{|c|c|c|c|c|c|}
\hline Country & Stock Exchange & Fiscal Year & Start Year & Firms & Weight (\%) \\
\hline \multicolumn{6}{|l|}{ Developed Markets } \\
\hline Australia & Australian & Jun & 1981 & 379 & 2.4 \\
\hline Austria & Vienna & Dec & 1989 & 50 & 0.4 \\
\hline Belgium & Brussels & Dec & 1988 & 64 & 0.8 \\
\hline Canada & Toronto & Dec & 1981 & 350 & 3.8 \\
\hline Denmark & Copenhagen & Dec & 1989 & 100 & 0.7 \\
\hline Finland & Helsinki & Dec & 1991 & 82 & 1.2 \\
\hline France & Paris & Dec & 1981 & 343 & 6.7 \\
\hline Germany & Frankfurt & Dec & 1981 & 300 & 5.2 \\
\hline Greece & Athens & Dec & 1994 & 181 & 0.7 \\
\hline Hong Kong & Hong Kong & Dec & 1988 & 312 & 2.9 \\
\hline Ireland & Dublin & Dec & 1990 & 35 & 0.4 \\
\hline Italy & Milan & Dec & 1981 & 112 & 2.2 \\
\hline Japan & Tokyo & Mar & 1981 & 1,324 & 24.2 \\
\hline Netherlands & Amsterdam & Dec & 1985 & 103 & 2.6 \\
\hline New Zealand & New Zealand & Jun & 1995 & 62 & 0.3 \\
\hline Norway & Oslo & Dec & 1988 & 104 & 1.0 \\
\hline Portugal & Lisbon & Dec & 1990 & 45 & 0.4 \\
\hline Singapore & Singapore & Dec & 1989 & 195 & 1.3 \\
\hline Spain & Madrid & Dec & 1988 & 85 & 2.8 \\
\hline Sweden & Stockholm & Dec & 1989 & 172 & 1.8 \\
\hline Switzerland & Zurich & Dec & 1986 & 124 & 2.3 \\
\hline United Kingdom & London & Dec & 1981 & 848 & 10.3 \\
\hline \multicolumn{6}{|l|}{ Emerging Markets } \\
\hline Argentina & Buenos Aires & Dec & 1998 & 49 & 0.4 \\
\hline Brazil & Sao Paulo & Dec & 2001 & 197 & 2.7 \\
\hline Chile & Santiago & Dec & 1993 & 90 & 0.8 \\
\hline China & Hong Kong, Shanghai, Shenzen & Dec & 1997 & 90 & 0.3 \\
\hline India & Bombay & Mar & 1993 & 343 & 3.0 \\
\hline Indonesia & Jakarta & Dec & 1992 & 139 & 0.6 \\
\hline Israel & Tel Aviv & Dec & 1998 & 50 & 0.7 \\
\hline Korea & Korea & Dec & 1990 & 351 & 2.7 \\
\hline Malaysia & Kuala Lumpur & Dec & 1986 & 293 & 1.1 \\
\hline Mexico & Mexico City & Dec & 1993 & 68 & 1.5 \\
\hline Pakistan & Karachi & Jun & 1994 & 60 & 0.2 \\
\hline Peru & Lima & Dec & 2000 & 45 & 0.2 \\
\hline Philippines & Manila & Dec & 1995 & 79 & 0.3 \\
\hline Russia & Moscow & Dec & 2004 & 70 & 4.8 \\
\hline South Africa & Johannesburg & Jun & 1987 & 156 & 1.4 \\
\hline Taiwan & Taiwan & Dec & 1994 & 385 & 3.6 \\
\hline Thailand & Thailand & Dec & 1992 & 218 & 0.7 \\
\hline Turkey & Istanbul & Dec & 1995 & 113 & 0.5 \\
\hline Total & & & 1981 & 6,664 & 100.0 \\
\hline
\end{tabular}




\section{B. Variables}

We closely follow the prior literature in defining the variables used in this study to facilitate comparisons. ${ }^{7}$ Size (ME) is market equity (price times shares outstanding) at the end of June of year $t$. Book-to-market equity (BM) is book value of common equity for the fiscal year ending in calendar year $t-1$ divided by market equity at the end of December of $t-1$. Momentum (MOM) is the cumulative prior 12-month stock return, lagged by 1 month to avoid the loss of return predictive power due to a bid-ask bounce (Jegadeesh (1990)). Following Loughran and Wellman (2011), the EM is defined as the enterprise value for the fiscal year ending in calendar year $t-1$ divided by EBITDA for $t-1 .^{8}$ The enterprise value is computed as market value of common equity plus total debt plus market value of preferred equity minus cash and short-term investments.

Table 2 presents equal-weighted summary statistics for the considered variables. A typical firm in our international sample has a size of $\$ 860$ million and a $\mathrm{BM}$ ratio of 0.9 . The magnitude of the momentum profit based on a stock's prior 12 -month return is $16.8 \%$. For the EM, we observe a mean of 10.5 and a median of 6.6. Loughran and Wellman (2011) report similar results for the U.S. market. Their average EM value is 11.3 and their median is 7.1, indicating a similar level of EM between U.S. and non-U.S. firms. Furthermore, with a mean (median) of 10.7 (6.7) for developed markets and a mean (median) of 10.5 (6.5) for emerging markets, the magnitude of the EM is also greatly comparable between the two market segments.

\section{TABLE 2}

\section{Summary Statistics for Variables}

Table 2 presents summary statistics including the mean, standard deviation, 25th percentile, median, and 75 th percentile for the variables. Market equity (ME) is price times shares outstanding at the end of June of year $t$ (in million U.S. dollars). Book-to-market equity (BM) is book value of common equity for the fiscal year ending in calendar year $t-1$ divided by market equity at the end of December of $t-1$. Momentum (MOM) is the prior 12-month stock return. The enterprise multiple $(E M)$ is defined as the enterprise value for the fiscal year ending in calendar year $t-1$ divided by earnings before interest, taxes, and depreciation (EBITDA) for $t-1$. The enterprise value is computed as market value of common equity plus total debt plus market value of preferred equity minus cash and short-term investments.

\begin{tabular}{|c|c|c|c|c|c|}
\hline Variable & Mean & SD & 25th & Median & 75th \\
\hline Market Equity (ME) & 860 & 2,649 & 58 & 177 & 550 \\
\hline Book-to-Market Equity (BM) & 0.9 & 0.8 & 0.4 & 0.6 & 1.1 \\
\hline Momentum (MOM) & 16.8 & 53.4 & -14.6 & 6.9 & 34.8 \\
\hline Enterprise Multiple (EM) & 10.5 & 17.8 & 4.5 & 6.6 & 10.2 \\
\hline
\end{tabular}

\section{Return Predictability of EM}

To obtain a first impression of the usefulness of the EM in markets outside the United States, we test whether EM is able to predict future stock returns in international markets using the Fama and MacBeth (1973) methodology.

\footnotetext{
${ }^{7}$ The Appendix presents definitions of the Datastream and Worldscope data in more detail.

${ }^{8} \mathrm{We}$ acknowledge that earnings in different countries do not have to mean the same thing from an accounting perspective. However, we are comfortable that our results are not driven by varying international standards. First, the Worldscope database standardizes accounting data to make economically meaningful comparisons between countries possible. Second, we address the issue of different accounting standards in Section $\mathrm{V}$ to further test the robustness of our results.
} 
Beside standard (equal-weighted) cross-sectional regressions, we also consider return-weighted regressions, where each stock return is weighted by the prior-month gross return. This technique has recently been proposed by Asparouhova, Bessembinder, and Kalcheva (2010), (2013) to control for the bias of noisy prices due to the bid-ask bounce in cross-sectional tests and thus ensures the robustness of our results. Undoubtedly, their approach has greatly enhanced our understanding of how microstructure noise can influence inferences in typical equal-weighted asset pricing tests and therefore the necessity to correct such biases through alternative weighting methods. ${ }^{9}$

Specifically, we estimate two different specifications of monthly crosssectional regressions. The objective of the first specification is to gauge the strength of the EM, when EM is used as the sole return predictor in the cross section of international returns, whereas the second specification shows whether the EM is able to predict future returns in the presence of common benchmark variables, in particular, size (ME), book-to-market equity (BM), and momentum (MOM). These variables are well known to have significant return predictability not only in the United States but also in international markets. ${ }^{10}$ If EM holds additional information about average returns beyond the other benchmark variables, then the average coefficient slope on the EM should be significant.

The regressions are estimated for the aggregate international markets sample and for four different subsamples based on market segmentation and size segmentation. Though risk and return characteristics in emerging markets have become more similar to those in developed markets in recent years, the two segments may still be considered distinct from each other (Harvey (1995), Eun and Lee (2010)). Therefore, we estimate regressions separately for developed markets and emerging markets. In this way, we bypass concerns that the aggregate evidence may just reflect a developed markets effect due to the larger number of sample stocks from this segment. Furthermore, a main interest is to clarify whether the return predictive ability of the EM holds for the largest and thus economically most important stocks that constitute almost nine-tenths of the sample's total market equity. Therefore, we split our sample in two strongly different size-segmented subsamples and estimate regressions separately for big stocks and all smaller stocks. Stocks with June market equity below the 80th size percentile are Not Big and those above are Big. ${ }^{11}$

Table 3 presents average coefficient slopes and their $t$-statistics from the two regression specifications, estimated for international markets and the four outlined subsamples. The explanatory variables in the regressions are either updated monthly or annually (at the end of June) to predict monthly returns from July of year $t$ to June of $t+1$. The EM, size, and book-to-market equity are measured annually, whereas momentum is updated monthly.

\footnotetext{
${ }^{9}$ Asparouhova et al. (2013) show that value weighting is similarly helpful to correct the bias of noisy prices. Therefore, the value-weighted EM value premiums in Section IV are free of such a bias.

${ }^{10} \mathrm{See}$, for instance, Heston et al. (1995), Fama and French (1998), and Rouwenhorst (1998) for size, BM value, and momentum in non-U.S. markets.

${ }^{11}$ This size grouping is similar to the one used in Fama and French (2006).
} 
TABLE 3

Average Slopes and $t$-Statistics from Monthly Cross-Sectional Regressions

Table 3 presents average coefficient slopes and their t-statistics (in parentheses) from cross-sectional regressions of monthly stock returns on (1) the enterprise multiple (EM) alone and (2) EM in conjunction with common benchmark variables (size (ME), book-to-market equity (BM), and momentum (MOM)). The regressions are estimated separately for marketsegmented subsamples (Developed and Emerging) and size-segmented subsamples (Not Big and Big). Stocks with June market equity below the 80th size percentile are Not Big and those above are Big. Explanatory variables in the regressions are either updated monthly or annually (at the end of June) to predict monthly returns from July of year $t$ to June of $t+1$. The variables $\mathrm{EM}, \mathrm{ME}$, and $\mathrm{BM}$ are measured annually, whereas MOM is updated monthly. In the regressions, EM, ME, and $\mathrm{BM}$ are measured in natural logs. INT is the average regression intercept. Panel A presents results for standard (equalweighted) cross-sectional regressions and Panel B for return-weighted regressions (weighting by the prior-month gross return) to control for the bias of noisy prices.

\begin{tabular}{|c|c|c|c|c|c|c|c|c|c|c|c|}
\hline & & & \multicolumn{4}{|c|}{ Market-Segmented } & \multicolumn{4}{|c|}{ Size-Segmented } \\
\hline & & \multicolumn{2}{|c|}{$\begin{array}{c}\text { International } \\
\text { Markets }\end{array}$} & Dev & oped & \multicolumn{2}{|c|}{ Emerging } & \multicolumn{2}{|c|}{ Not Big } & \multicolumn{2}{|c|}{ Big } \\
\hline \multicolumn{12}{|c|}{ Panel A. Equal-Weighted Regressions } \\
\hline (1) & $\begin{array}{l}\text { INT } \\
\text { EM }\end{array}$ & $\begin{array}{r}2.26 \\
-0.52\end{array}$ & $\begin{array}{r}(9.00) \\
(-6.82)\end{array}$ & $\begin{array}{r}2.12 \\
-0.51\end{array}$ & $\begin{array}{r}(8.60) \\
(-6.15)\end{array}$ & $\begin{array}{r}2.34 \\
-0.54\end{array}$ & $\begin{array}{r}(4.93) \\
(-3.68)\end{array}$ & $\begin{array}{r}2.27 \\
-0.50\end{array}$ & $\begin{array}{r}(9.08) \\
(-6.83)\end{array}$ & $\begin{array}{r}2.20 \\
-0.55\end{array}$ & $\begin{array}{r}(6.62) \\
(-4.51)\end{array}$ \\
\hline (2) & $\begin{array}{l}\text { INT } \\
\text { EM } \\
\text { ME } \\
\text { BM } \\
\text { MOM }\end{array}$ & $\begin{array}{r}2.33 \\
-0.32 \\
-0.11 \\
0.30 \\
0.83\end{array}$ & $\begin{array}{r}(8.21) \\
(-4.92) \\
(-3.45) \\
(4.44) \\
(3.79)\end{array}$ & $\begin{array}{r}2.22 \\
-0.32 \\
-0.11 \\
0.25 \\
0.93\end{array}$ & $\begin{array}{r}(7.68) \\
(-4.81) \\
(-3.28) \\
(3.63) \\
(4.25)\end{array}$ & $\begin{array}{r}2.25 \\
-0.35 \\
-0.16 \\
0.38 \\
0.37\end{array}$ & $\begin{array}{r}(4.95) \\
(-2.74) \\
(-2.38) \\
(2.60) \\
(0.96)\end{array}$ & $\begin{array}{r}2.90 \\
-0.29 \\
-0.27 \\
0.28 \\
0.94\end{array}$ & $\begin{array}{r}(9.79) \\
(-4.51) \\
(-6.32) \\
(4.23) \\
(4.43)\end{array}$ & $\begin{array}{r}1.91 \\
-0.40 \\
-0.02 \\
0.22 \\
0.56\end{array}$ & $\begin{array}{r}(3.91) \\
(-4.06) \\
(-0.42) \\
(1.67) \\
(1.59)\end{array}$ \\
\hline \multicolumn{12}{|c|}{ Panel B. Return-Weighted Regressions } \\
\hline (1) & $\begin{array}{l}\text { INT } \\
\text { EM }\end{array}$ & $\begin{array}{r}2.28 \\
-0.52\end{array}$ & $\begin{array}{r}(8.87) \\
(-6.73)\end{array}$ & $\begin{array}{r}2.13 \\
-0.51\end{array}$ & $\begin{array}{r}(8.46) \\
(-6.14)\end{array}$ & $\begin{array}{r}2.26 \\
-0.49\end{array}$ & $\begin{array}{r}(4.47) \\
(-3.10)\end{array}$ & $\begin{array}{r}2.27 \\
-0.50\end{array}$ & $\begin{array}{r}(8.83) \\
(-6.46)\end{array}$ & $\begin{array}{r}1.96 \\
-0.55\end{array}$ & $\begin{array}{r}(6.49) \\
(-3.94)\end{array}$ \\
\hline (2) & $\begin{array}{l}\text { INT } \\
\text { EM } \\
\text { ME } \\
\text { BM } \\
\text { MOM }\end{array}$ & $\begin{array}{r}2.34 \\
-0.28 \\
-0.14 \\
0.25 \\
1.03\end{array}$ & $\begin{array}{r}(8.05) \\
(-3.69) \\
(-3.32) \\
(2.40) \\
(4.29)\end{array}$ & $\begin{array}{r}2.24 \\
-0.30 \\
-0.12 \\
0.23 \\
1.28\end{array}$ & $\begin{array}{r}(7.50) \\
(-4.11) \\
(-3.42) \\
(3.25) \\
(5.99)\end{array}$ & $\begin{array}{r}2.19 \\
-0.33 \\
-0.17 \\
0.34 \\
0.75\end{array}$ & $\begin{array}{r}(4.55) \\
(-2.59) \\
(-2.04) \\
(2.12) \\
(2.08)\end{array}$ & $\begin{array}{r}2.83 \\
-0.26 \\
-0.26 \\
0.27 \\
1.27\end{array}$ & $\begin{array}{r}(9.05) \\
(-3.56) \\
(-5.51) \\
(3.68) \\
(6.32)\end{array}$ & $\begin{array}{r}1.78 \\
-0.38 \\
-0.02 \\
0.17 \\
0.53\end{array}$ & $\begin{array}{r}(3.53) \\
(-3.89) \\
(-0.48) \\
(1.10) \\
(1.31)\end{array}$ \\
\hline
\end{tabular}

Regarding first the estimates from equal-weighted regressions in Panel A of Table 3, we find in the first specification an economically meaningful and statistically significant average coefficient slope on EM of -0.52 with a $t$-statistic of -6.82 , thus confirming out of sample the negative relation between the EM and average returns in international markets. Furthermore, the results of the subsample regressions indicate that the return predictive power of EM is similarly pronounced in developed markets and emerging markets and likewise strong for big firms and all smaller firms. The coefficients on the EM are highly significant in all subsamples and similar in magnitude to the aggregate international markets sample. Compared to the U.S. evidence, the EM value effect appears to be stronger in markets outside the United States. Loughran and Wellman (2011) report for the same regression specification an average EM slope of -0.33 ( $t$-statistic $=-5.36$ ).

When we move on to the estimates of the second regression specification, where EM is combined with common benchmark variables, we observe that EM is not explained away in the presence of the typically used average-return predictors. In fact, the EM remains the strongest variable in terms of statistical significance in international markets, developed as well as emerging markets, and what is even more remarkable, big firms.

The reduction in absolute magnitude of EM by about one-third from the first specification to the second specification indicates that the EM shares part of the information contained in the other determinants of the cross section. We will shed 
more light on this issue in the next section, where we attempt to explain the EM value premium by its exposure to common return factors of existing asset pricing models.

The average slopes on the common benchmark variables echo prior results in the literature. International returns are negatively related to size and positively to book-to-market equity and momentum with significant $t$-statistics on the respective coefficients. In the two market segments, the average MOM slope is positive, but statistically significant momentum profits are produced only in developed markets. The weaker momentum effect for emerging markets firms is, however, in line with prior evidence (e.g., Rouwenhorst (1999), Griffin, Ji, and Martin (2003), and Chui, Titman, and Wei (2010)). While the EM maintains its return predictive ability among big stocks, the other determinants of the cross section decrease in strength. However, this last finding is again consistent with previous findings on size, BM value, and momentum exhibiting a varying power with respect to firm size (e.g., Loughran (1997), Hong, Lim, and Stein (2000), Horowitz, Loughran, and Savin (2000), and Fama and French (2006), (2008), (2012)).

Moving to the return-weighted results in Panel B of Table 3, we detect a moderate upward bias in the equal-weighted EM estimates of about 10\%, which is corrected in the return-weighted regressions. The magnitude is comparable to the bias identified for the likewise accounting-based BM estimates and similar to the one reported in Asparouhova et al. (2013) for the U.S. BM variable. In summary, our general inferences are not driven by microstructure noise of security prices.

The cross-sectional regression technique is useful for identifying variables with return predictive power. However, given the fact that in a standard Fama-MacBeth (1973) regression each stock is treated equally, the economic substance of the results is not always easy to assess (see Fama and French (2006)). To mitigate this concern, we focus in the next section on value-weighted portfolios formed on the EM. The portfolio outcomes are easy to interpret, and the use of value-weighted returns leads to economically more meaningful results as they capture the return behavior in a way that corresponds to realistic investment opportunities (see Fama and French (1993)).

\section{EM Value Premiums}

\section{A. International and Country Returns}

How large is the EM value premium in international markets and how pervasive is it in individual countries? Following Loughran and Wellman (2011), we study the EM strategy by forming international and country zero-investment portfolios that go long low-EM firms and short high-EM firms capturing the EM value premium in average returns.

At the aggregate international level, we create the EM value premium (enterprise multiple difference (EMD)) in June (Fama and French (1992), (1993)), as the fiscal year coincides with the calendar year for the vast majority of firms in the international sample (see Table 1). However, at the country level, we adopt country-specific conventions. That is, for markets with non-December fiscal year 
ends, individual country portfolios are formed analogously in September (Japan and India, due to March as fiscal year end) and December (Australia, New Zealand, Pakistan, and South Africa, due to June as fiscal year end) to attain the commonly used 6-month lag between the fiscal year end and the portfolio formation date (e.g., Fama and French (1993)).

By way of illustration, the EM value premium for markets with December fiscal year ends is created each June from a two-by-three sort on market equity (as of the portfolio formation date) and the EM (for the fiscal year ending in calendar year $t-1$ ) forming 6 value-weighted portfolios. The size sort uses the median as a breakpoint, whereas the breakpoints for the EM sort are based on the 30th and 70th percentiles. Monthly returns on the portfolios are calculated from July of year $t$ to June of $t+1$, and the portfolios are rebalanced in June of $t+1$. EMD is the simple average of the returns on the two low-EM portfolios minus the average on the two high-EM portfolios. The international EM value premium uses all stocks across countries, whereas the country premiums use only stocks within the considered country.

As the cross-sectional regression tests in the previous section have used largely aggregated samples across countries, it is interesting to investigate the extent to which the EM value effect holds in individual countries. In this way, we address the concern that the international EM value effect may be driven just by a few countries that make up the majority of sample stocks. Furthermore, though we have previously controlled for firm size at the aggregate level, a stock that may be considered large in a small country would likely be treated as a small stock in an international sample. Therefore, the country analyses provide additional insights into the strength and pervasiveness of the EM value premium by taking country-specific stock market conditions into account.

Table 4 presents summary statistics for the average EM value premiums in international markets and individual countries. As in the United States, low-EM firms significantly outperform high-EM firms, resulting in an international EM value premium of $0.97 \%$ per month with a $t$-statistic of 6.97 . By being more than twice as large as the corresponding U.S. premium reported in Loughran and Wellman (2011), the EM strategy appears to be even more promising in markets outside the United States.

Looking at the portfolios forming the EM value premium, we notice that the strong performance of the EM strategy comes from both ends, that is, from lowEM firms earning in general higher average excess returns of more than $1 \%$ per month and from high-EM firms yielding in general lower average excess returns that are statistically indistinguishable from 0 .

Similar to the aggregate international markets, the country premiums in Panel B of Table 4 are positive in all countries and statistically significant in the majority of the individual markets. Among the 22 developed markets, we find 18 countries where the EM value premium is more than 2 standard errors from 0 . The significant premiums range in magnitude from $0.55 \%$ per month in Japan to $1.22 \%$ per month in Portugal.

In emerging markets, stock returns are on average more volatile than in developed markets and therefore obtaining significant results at the country level can be more challenging (Fama and French (1998)). Nevertheless, we still find 
TABLE 4

Summary Statistics for Monthly EM Value Premiums (EMD)

Table 4 presents average monthly excess returns and the corresponding $t$-statistics (in parentheses) for low- and highEM portfolios, along with the average monthly EM value premium (enterprise multiple difference (EMD)) in international markets and individual countries. The EM value premium is created in general each June from a two-by-three sort on market equity (as of the portfolio formation date) and the EM (for the fiscal year ending in calendar year $t-1)$ forming 6 value-weighted portfolios. The size sort uses the median as a breakpoint, whereas the breakpoints for the EM sort are based on the 30th and 70th percentiles. Monthly returns on the portfolios are calculated from July of year $t$ to June of $t+1$. EMD is the simple average of the returns on the 2 low-EM portfolios minus the average on the 2 high-EM portfolios. The international EM value premium (in Panel A) uses all stocks across countries, whereas the country premiums (in Panel B) use only stocks within the considered country. For countries with non-December fiscal year ends, the portfolios are formed analogously in September (Japan and India) and December (Australia, New Zealand, Pakistan, and South Africa). The start year of returns for each country and the average number of firms included in the portfolios are provided in Table 1.

\section{Country \\ Panel A. International Markets}

Low EM

(4.78)

0.27

High EM

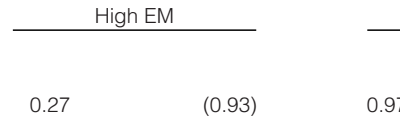

EMD

Panel B. Individual Countries

\section{Developed Markets}

Australia

Austria

Belgium

Canada

Denmark

Finland

France

Germany

Greece

Hong Kong

Ireland

Italy

Japan

Netherlands

New Zealand

Norway

Portugal

Singapore

Spain

Sweden

Switzerland

United Kingdom

Emerging Markets

Argentina

Brazil

Chile

China

India

Indonesia

Israel

Korea

Malaysia

Mexico

Pakistan

Peru

Philippines

Russia

South Africa

Taiwan

Thailand

Turkey

$\begin{array}{ll}1.37 & (3.64) \\ 1.04 & (2.19) \\ 0.87 & (2.90) \\ 1.08 & (3.70) \\ 0.72 & (2.11) \\ 1.19 & (2.60) \\ 1.29 & (4.07) \\ 0.87 & (3.00) \\ 1.07 & (1.37) \\ 1.12 & (2.33) \\ 0.72 & (1.55) \\ 0.74 & (1.94) \\ 0.71 & (2.09) \\ 1.06 & (3.12) \\ 1.00 & (2.03) \\ 1.39 & (3.50) \\ 1.06 & (2.56) \\ 1.28 & (2.46) \\ 0.96 & (2.56) \\ 1.25 & (2.86) \\ 1.11 & (3.45) \\ 1.12 & (3.83) \\ & \\ 1.00 & (1.15) \\ 3.50 & (3.93) \\ 0.95 & (1.93) \\ 2.00 & (1.96) \\ 1.96 & (2.70) \\ 1.79 & (1.92) \\ 1.49 & (2.23) \\ 1.19 & (1.62) \\ 1.33 & (2.37) \\ 1.04 & (1.68) \\ 1.36 & (2.22) \\ 2.92 & (3.38) \\ 0.99 & (1.28) \\ 2.38 & (1.71) \\ 1.15 & (2.58) \\ 0.64 & (1.01) \\ 1.48 & (2.62) \\ 2.33 & (1.99)\end{array}$

$\begin{array}{r}0.22 \\ 0.04 \\ 0.03 \\ 0.48 \\ 0.33 \\ 0.84 \\ 0.47 \\ 0.12 \\ 0.15 \\ 0.92 \\ 0.47 \\ -0.01 \\ 0.16 \\ 0.23 \\ 0.34 \\ 0.42 \\ -0.16 \\ 0.39 \\ 0.14 \\ 0.24 \\ -0.03 \\ 0.30 \\ \hline\end{array}$

\section{(0.52)}

(0.09)

$(0.08)$

(1.33)

(1.00)

(1.47)

(1.42)

(0.40)

(0.19)

(1.65)

(1.06)

(-0.02)

(0.39)

(0.64)

(0.68)

(0.80)

$(-0.31)$

(0.76)

(0.33)

(0.46)

(-0.10)

(0.97)

$(-0.03)$

(2.04)

(0.97)

(0.86)

(2.29)

(0.83)

(1.31)

(0.24)

(1.21)

(1.06)

$(-0.08)$

(1.84)

$(-0.02)$

(1.37)

(0.63)

$(0.55)$

(0.66)

$(0.66)$
$(1.62)$

significant EM value premiums in eight from 18 emerging markets with magnitudes comparable to those from developed markets. Malaysia has the smallest significant EMD return (0.53\%), whereas Brazil has the largest (1.39\%).

In summary, the individual country results confirm the findings at the aggregate international level, making the EM value premium a rather pervasive phenomenon around the world. 


\section{B. Robustness to Common Return Factors and U.S. Comovement}

Can the EM value premiums be explained by existing asset pricing models? We address this question by using international and country versions of the capital asset pricing model (CAPM), the 3-factor model of Fama and French (1993), and the 4-factor model of Carhart (1997) to describe average returns on EMD in international markets and individual countries. We estimate the following timeseries regressions:

$$
\begin{aligned}
& \mathrm{EMD}=a+b \mathrm{MKT}+u \\
& \mathrm{EMD}=a+b \mathrm{MKT}+s \mathrm{SMB}+h \mathrm{HML}+u \\
& \mathrm{EMD}=a+b \mathrm{MKT}+s \mathrm{SMB}+h \mathrm{HML}+w \mathrm{WML}+u .
\end{aligned}
$$

In these regressions, EMD is the return on the EM value premium, MKT is the market excess return, and SMB, HML, and WML, are, respectively, the returns on the explanatory factors related to size, $\mathrm{BM}$ value, and momentum. The regressions use international return factors to explain the international EMD return and country-specific factors to describe the EM value premium in a given country. The alpha estimate, $a$, shows the average return left unexplained by the model, and $u$ is the regression residual. Regressions (1), (2), and (3) denote the CAPM, 3-factor model, and 4-factor model, respectively. If a model is able to describe the average EM value premium, the regression intercept should be statistically indistinguishable from 0 .

The return factors used in these regression tests are constructed as follows: The market factor (MKT) is the return on a value-weighted portfolio of all stocks across countries or within a country in excess of the 1-month U.S. Treasury bill rate. Following the original approach of Fama and French (1993), we use doublesorted portfolios for the construction of the common benchmark factors. ${ }^{12}$ The size and BM value factors are created in general each June from a two-by-three sort on market equity and book-to-market equity forming six value-weighted portfolios. ${ }^{13} \mathrm{SMB}$ is the simple average of the returns on the three small-stock portfolios minus the average on the three big-stock portfolios. HML is the simple average of the returns on the two high-BM portfolios minus the average on the two low-BM portfolios. The momentum factor is formed monthly using a two-bythree sort on market equity and the cumulative prior 12-month return (skipping the most recent month (Jegadeesh (1990)) creating six value-weighted portfolios. WML is the simple average of the returns on the two high-prior-return portfolios minus the average on the two low-prior-return portfolios. Market equity and the cumulative prior 12-month return are measured as of the portfolio formation date, whereas book-to-market equity is for the fiscal year ending in calendar year $t-1$. The size sort uses the median as a breakpoint, whereas the breakpoints for the second sorting variable are based on the 30th and 70th percentiles. The international

\footnotetext{
${ }^{12}$ Fama and French (2012) suggest a specific construction for the SMB, HML, and WML factors when used in regions. Griffin (2002) forms global versions of SMB and HML as weighted averages of the underlying country factors. We have tested both methodological approaches for our international versions with similar results in comparison to our pooling approach.

${ }^{13}$ The exceptions at the country level when forming EMD portfolios apply to the explanatory factors as well.
} 
versions of the explanatory factors use all stocks across countries, whereas the country versions use only stocks within the considered country.

For perspective, the average international market premium for the sample period $1981-2010$ is $0.54 \%$ per month $(t$-statistic $=1.94) .{ }^{14}$ The average international SMB return is $0.24 \%$ per month, but not statistically distinguishable from 0 $(t$-statistic $=1.88)$. As in Fama and French (1998), we find that the international value premium based on HML is particularly strong and larger than the U.S. BM value premium. ${ }^{15}$ The average HML return amounts to $0.79 \%$ per month with a $t$-statistic of 4.55 . Of the considered benchmark factors, WML produces the largest premium, with an average value of $0.94 \%$ per month $(t$-statistic $=3.74)$. Without going into detail, the country-specific factors mostly reflect the aggregate international evidence of a weak SMB return, but strong HML and WML returns. However, the average premiums on the factors vary in magnitude and significance from country to country. Therefore, the use of country-specific factors is crucial for obtaining sound results in the country-level analyses (Griffin (2002)).

In addition, we investigate whether there is any comovement between nonU.S. and U.S. EM value premiums. Due to the strong similarity between our international findings and the U.S. evidence in Loughran and Wellman (2011), there might be a common component in the EM strategies across equity markets. To test for potential covariations, we estimate time-series regressions of the international and country EM value premiums on the U.S. EMD return:

$$
\mathrm{EMD}=a+e \mathrm{EMD}(\mathrm{US})+u .
$$

In this regression, $a$, the alpha estimate, provides the average EM value premium, which is independent from the U.S. premium. ${ }^{16}$ Such a test is commonly used to investigate the degree of comovement between international and U.S. strategies (e.g., in Rouwenhorst (1998) and Ang et al. (2009)). Given the finding in Ang et al. that the U.S. return premium can fully explain international premiums formed on the same variable, controlling for comovement with the initial U.S. evidence also seems to be important to allay robustness concerns.

Table 5 presents regression results to explain EM value premiums in international markets and individual countries. Regressing the international EMD return in Panel A of Table 5 on the market factor produces a large and significant alpha estimate of $1.04 \%$ per month $(t$-statistic $=6.72)$ with a low adjusted $R^{2}$ value of 0.07 . Thus, the EM value premium cannot be explained by the sole market beta of the CAPM. However, controlling for the additional return factors of the 3 -factor and 4-factor models does not render EMD insignificant, either. In fact, the 4-factor alpha remains economically meaningful and statistically significant with

\footnotetext{
${ }^{14}$ The 1 -month U.S. Treasury bill rate is $0.41 \%$ per month $(t$-statistic $=31.80)$ during the sample period.

${ }^{15}$ For comparison, the average U.S. HML return during the same time period is $0.40 \%$ per month $(t$-statistic $=2.37)$. We thank Kenneth French for making the data publicly available at http://mba.tuck.dartmouth.edu/pages/faculty/ken.french/data_library.html.

${ }^{16}$ Data on the U.S. EM value premium are publicly available at http://www.nd.edu/ tloughra/. The average U.S. EMD return is $0.51 \%$ per month $(t$-statistic $=3.49)$ during the period July 1981 to Dec. 2009. The time series ends 6 months earlier than our sample period. However, due to the long period under review, this reduction is negligible. We thank Tim Loughran for making the data available.
} 
TABLE 5

Time-Series Regressions to Explain Monthly EM Value Premiums

Table 5 presents regression results to explain monthly EM value premiums in international markets and individual countries The $t$-statistics (in parentheses) use the Newey and West (1987) heteroskedasticity and autocorrelation consistent standard errors. The $R^{2}$ is adjusted for degrees of freedom. Panel A presents alpha estimates and factor loadings from regressing the international EM value premium on the international return factors of the CAPM, 3-factor, and 4-factor models, as well as the U.S. EM value premium (EMD(US)). Panel B presents alpha estimates from regressing country EM value premiums on the country-specific return factors of the 4-factor model, as well as the U.S. EM value premium.

Panel A. International Markets

\begin{tabular}{|c|c|c|c|c|c|c|c|}
\hline Regression & a & $b$ & $s$ & $h$ & $w$ & e & $R^{2}$ \\
\hline CAPM & $\begin{array}{c}1.04 \\
(6.72)\end{array}$ & $\begin{array}{c}-0.14 \\
(-3.15)\end{array}$ & & & & & 0.07 \\
\hline 3-Factor & $\begin{array}{c}0.74 \\
(5.16)\end{array}$ & $\begin{array}{l}-0.09 \\
(-2.15)\end{array}$ & $\begin{array}{c}-0.18 \\
(-2.41)\end{array}$ & $\begin{array}{c}0.40 \\
(6.59)\end{array}$ & & & 0.32 \\
\hline 4-Factor & $\begin{array}{c}0.61 \\
(4.42)\end{array}$ & $\begin{array}{c}-0.06 \\
(-1.46)\end{array}$ & $\begin{array}{l}-0.16 \\
(-2.30)\end{array}$ & $\begin{array}{c}0.38 \\
(6.46)\end{array}$ & $\begin{array}{c}0.14 \\
(2.85)\end{array}$ & & 0.38 \\
\hline EMD(US) & $\begin{array}{c}0.84 \\
(5.32)\end{array}$ & & & & & $\begin{array}{c}0.26 \\
(5.98)\end{array}$ & 0.07 \\
\hline
\end{tabular}

$\underline{\text { Panel B. Individual Countries }}$

\begin{tabular}{|c|c|c|c|c|c|c|c|c|c|}
\hline \multirow{2}{*}{$\frac{\text { Country }}{\text { Developed Markets }}$} & \multicolumn{2}{|c|}{ 4-Factor } & \multicolumn{2}{|c|}{ EMD(US) } & \multirow{2}{*}{\multicolumn{2}{|c|}{$\frac{\text { Country }}{\text { Emerging Markets }}$}} & 4-Factor & \multicolumn{2}{|c|}{$\mathrm{EMD}(\mathrm{US})$} \\
\hline & & & & & & & & & \\
\hline Australia & 0.91 & $(4.76)$ & 1.14 & $(5.29)$ & Argentina & 1.16 & $(2.46)$ & 0.89 & (1.81) \\
\hline Austria & 0.69 & (1.95) & 1.03 & $(2.21)$ & Brazil & 1.54 & (3.87) & 1.51 & (2.89) \\
\hline Belgium & 0.41 & $(2.00)$ & 0.81 & (3.09) & Chile & 0.07 & $(0.18)$ & 0.51 & $(1.26)$ \\
\hline Canada & 0.48 & $(2.18)$ & 0.43 & $(2.28)$ & China & 0.71 & $(1.76)$ & 0.88 & (1.54) \\
\hline Denmark & 0.03 & $(0.17)$ & 0.32 & (1.43) & India & 0.37 & $(1.56)$ & 0.12 & (0.33) \\
\hline Finland & 0.37 & (1.10) & -0.02 & $(-0.04)$ & Indonesia & 1.03 & (1.89) & 1.03 & (1.61) \\
\hline France & 0.31 & (1.91) & 0.58 & $(2.53)$ & Israel & 0.84 & (1.65) & 0.54 & $(0.82)$ \\
\hline Germany & 0.26 & $(1.75)$ & 0.52 & (3.28) & Korea & 0.78 & (2.64) & 0.93 & (2.42) \\
\hline Greece & 0.77 & (2.05) & 1.01 & (2.62) & Malaysia & 0.59 & (3.28) & 0.45 & (2.02) \\
\hline Hong Kong & 0.36 & (1.23) & 0.04 & $(0.11)$ & Mexico & 0.11 & (0.34) & 0.39 & (1.10) \\
\hline Ireland & -0.09 & $(-0.23)$ & 0.17 & $(0.38)$ & Pakistan & 1.40 & (3.45) & 1.41 & (3.74) \\
\hline Italy & 0.52 & $(2.21)$ & 0.62 & (2.33) & Peru & 1.26 & (1.72) & 1.52 & (1.74) \\
\hline Japan & 0.36 & (2.65) & 0.46 & (2.78) & Philippines & 0.88 & (2.06) & 0.91 & (1.92) \\
\hline Netherlands & 0.71 & (2.61) & 0.77 & (3.08) & Russia & 0.47 & $(0.98)$ & 0.42 & (0.62) \\
\hline New Zealand & 0.36 & (1.06) & 0.71 & (2.98) & South Africa & 0.86 & (2.55) & 0.83 & (2.48) \\
\hline Norway & 1.01 & (3.56) & 0.81 & (2.53) & Taiwan & 0.31 & (1.13) & 0.23 & $(0.76)$ \\
\hline Portugal & 1.20 & (3.17) & 1.17 & $(2.91)$ & Thailand & 1.03 & (2.79) & 1.02 & $(2.30)$ \\
\hline Singapore & 0.80 & (3.54) & 0.83 & $(3.45)$ & Turkey & 0.43 & (0.92) & 0.56 & (0.98) \\
\hline Spain & 0.61 & (2.86) & 0.75 & (3.43) & & & & & \\
\hline Sweden & 0.58 & (1.88) & 0.67 & (1.77) & & & & & \\
\hline Switzerland & 0.79 & (5.47) & 1.09 & $(6.46)$ & & & & & \\
\hline United Kingdom & 0.52 & $(4.61)$ & 0.65 & (3.77) & & & & & \\
\hline
\end{tabular}

a magnitude of $0.61 \%$ per month and a $t$-statistic of 4.42 . Hence, similar to the U.S. evidence in Loughran and Wellman (2011), the EM strategy in international markets remains robust and earns significantly positive (abnormal) returns even after controlling for exposures to size, BM value, and momentum.

From the factor loadings, we learn that the performance of the EM value premium does not rely on small stocks. However, as expected, EMD loads strongly positive on the value factor, HML, albeit it is not subsumed by the BM value premium. An interesting feature is that the EM strategy exhibits a positive and significant exposure to the momentum factor. This rather intriguing result for a typical value strategy can, however, be explained by the fact that earnings and price momentum are positively related as set forth in Chordia and Shivakumar (2006) for the U.S. market, and in Hong, Lee, and Swaminathan (2003) for international markets.

Regarding the results from regression (4) shows that the international EM value premium exhibits a moderate exposure to the U.S. EMD return, indicating 
the existence of a common component between the EM strategies in international markets and the United States. However, the U.S. effect does not capture the international effect comprehensively. The alpha estimate, which provides the international EM value premium conditional on the U.S. experience, remains large in magnitude with $0.84 \%$ per month and highly significant with a $t$-statistic of 5.32. Hence, the international EM value premium is likewise robust after controlling for comovement with the respective U.S. premium.

We now turn to the average EM value premiums in individual countries in Panel B of Table 5. Saving space, we report next to the alpha estimates from regression (4) only the alpha estimates of the 4-factor model, because it captures the largest portion of return variation on EMD for the considered asset pricing models. However, nontabulated results confirm that the significant country EM value premiums are left unexplained by the country-specific versions of the CAPM as well as the 3-factor model throughout all individual countries.

Among the 26 countries exhibiting a significant EMD return (in Panel B of Table 4), 21 of them cannot be explained by their exposures to the corresponding country MKT, SMB, HML, and WML factors, as indicated by the significant alpha estimates in the 4-factor column. Among the countries with significant alphas are the major equity markets of Japan and the United Kingdom, where most of the invested money is located. However, the EM value premium is robust in many smaller countries in terms of sample firms and total market equity from developed markets as well as emerging markets. The characteristics of the size, BM value, and momentum factors largely coincide with the findings at the aggregate international level in the vast majority of countries.

Similar to the international evidence, country EM value premiums exhibit a moderate exposure to the U.S. EMD return (not tabulated). Unsurprisingly, developed markets display stronger comovements with the United States than emerging markets. The average loading on the U.S. EMD return across the two market segments is 0.30 versus 0.09 . However, the country EM value premiums conditional on the U.S. data remain on average large in magnitude and significant in 23 countries, as indicated by the alpha estimates in the EMD(US) columns. $^{17}$

\section{Persistence of the EM Strategy}

How persistent is the EM value premium over longer horizons? We address this question by examining the (abnormal) year-to-year performance of the EM strategy for holding periods up to 5 years. Our test setting is similar to Titman, Wei, and Xie (2004), (2009).

First, each June we create 125 value-weighted benchmark portfolios by independently allocating all stocks in the sample to 5 size groups, 5 BM groups, and 5 momentum groups based on the quintile breakpoints for the variables. Monthly returns on the portfolios are calculated for the subsequent 12 months, and the portfolios are rebalanced yearly. Market equity and the cumulative prior 12-month

\footnotetext{
${ }^{17}$ Adding the U.S. EMD return to the 4-factor model does not add much to the explanation of nonU.S. EMD returns. The EM value premiums remain robust in international markets and in half of the individual countries.
} 
return are measured as of the portfolio formation date, whereas book-to-market equity is for the fiscal year ending in calendar year $t-1$.

Then, the monthly return on a stock is measured net of the return on its matching benchmark portfolio based on market equity, book-to-market equity, and momentum. The benchmark-adjusted returns are used afterward to calculate value-weighted returns on the portfolios forming the EM value premium. According to Fama and French (2008), the average benchmark-adjusted return on a portfolio is similar to the alpha estimate based on a multifactor model using the corresponding benchmark variables for its explanatory factors (irrespective of a market factor). Though the average benchmark-adjusted returns may correspond to 4-factor alphas, the use of benchmark-adjusted returns also shows whether the EM value premium is robust to controls of characteristics instead of return factors. ${ }^{18}$

Table 6 presents the (abnormal) year-to-year performance of the EM strategy in international markets. The table reports annualized benchmark-adjusted returns

TABLE 6

Year-to-Year Benchmark-Adjusted Returns of the Enterprise Multiple Strategy

Table 6 presents year-to-year benchmark-adjusted returns on the EM value premium in international markets. The monthly return on a stock is measured net of the return on its matching benchmark portfolio based on market equity, book-to-market equity, and momentum. The 125 value-weighted benchmark portfolios are created each June by independently allocating all stocks in the sample to 5 size groups, 5 BM groups, and 5 momentum groups based on the quintile breakpoints for the variables. The table reports annualized benchmark-adjusted returns on EMD for 1 to 5 years after portfolio formation. The annualized return in each year is calculated by compounding the 12 monthly returns from July of year $t$ to June of $t+1$. The last row gives the average benchmark-adjusted return in each of the 5 years after portfolio formation and the corresponding $t$-statistic (in parentheses).

\begin{tabular}{|c|c|c|c|c|c|}
\hline Formation & Year 1 & Year 2 & Year 3 & Year 4 & Year 5 \\
\hline 1981 & 3.41 & 3.95 & 5.83 & -4.50 & 7.27 \\
\hline 1982 & 1.82 & 8.64 & 2.22 & 13.84 & 0.58 \\
\hline 1983 & 12.45 & -1.57 & 11.67 & 0.80 & 1.81 \\
\hline 1984 & 2.59 & 18.81 & -1.35 & -3.62 & 4.51 \\
\hline 1985 & 9.70 & -1.74 & -1.64 & 7.76 & 4.10 \\
\hline 1986 & -0.14 & 3.75 & 7.07 & 1.64 & -6.79 \\
\hline 1987 & 1.23 & 5.92 & -1.79 & -6.59 & 1.43 \\
\hline 1988 & 6.95 & 7.19 & -7.35 & 5.47 & -5.17 \\
\hline 1989 & 5.00 & 0.16 & 9.71 & -5.62 & 2.34 \\
\hline 1990 & 2.15 & 10.03 & -6.92 & 1.07 & 13.37 \\
\hline 1991 & 15.36 & -9.42 & 5.03 & 15.16 & -12.43 \\
\hline 1992 & -7.74 & 2.19 & 17.02 & -10.97 & 24.49 \\
\hline 1993 & 0.20 & 10.71 & -2.66 & 18.24 & 26.43 \\
\hline 1994 & 13.14 & 1.99 & 14.34 & 33.04 & -11.23 \\
\hline 1995 & 7.03 & 25.68 & 33.33 & -6.34 & 1.96 \\
\hline 1996 & 16.48 & 30.95 & -7.35 & 6.37 & 6.60 \\
\hline 1997 & 27.04 & 3.93 & -2.23 & 9.29 & 20.15 \\
\hline 1998 & 0.81 & -4.16 & 9.89 & 10.69 & 3.91 \\
\hline 1999 & 3.53 & 8.30 & 20.48 & 6.77 & 1.06 \\
\hline 2000 & 17.14 & 13.03 & 5.55 & -2.50 & 9.78 \\
\hline 2001 & 19.50 & 11.33 & 1.34 & 15.57 & 8.34 \\
\hline 2002 & 10.17 & 3.57 & 18.90 & 4.48 & 3.92 \\
\hline 2003 & 4.49 & 21.12 & 3.20 & 11.11 & 6.31 \\
\hline 2004 & 16.40 & 2.71 & 5.18 & 3.21 & -2.31 \\
\hline 2005 & 4.86 & 9.00 & 8.86 & -2.86 & 6.91 \\
\hline 2006 & 9.74 & 6.86 & -1.50 & 4.63 & \\
\hline 2007 & 9.67 & -3.89 & 6.28 & & \\
\hline 2008 & 0.15 & 8.79 & & & \\
\hline 2009 & 11.08 & & & & \\
\hline Mean & $\begin{array}{c}7.73 \\
(5.59)\end{array}$ & $\begin{array}{c}7.07 \\
(4.17)\end{array}$ & $\begin{array}{c}5.67 \\
(3.12)\end{array}$ & $\begin{array}{c}4.85 \\
(2.57)\end{array}$ & $\begin{array}{c}4.69 \\
(2.49)\end{array}$ \\
\hline
\end{tabular}

\footnotetext{
${ }^{18}$ See, in particular, a discussion on this issue in Daniel and Titman (1997) and Davis, Fama, and French (2000).
} 
on EMD for 1 to 5 years after portfolio formation. The annualized return in each year is calculated by compounding the 12 monthly returns from July of year $t$ to June of $t+1$.

Focusing on the average benchmark-adjusted returns in the last row of Table 6 shows that the EM strategy is strongly persistent. Low-EM firms outperform high-EM firms after controlling for size, BM value, and momentum for up to 5 years after portfolio formation. The average annualized benchmark-adjusted returns are all statistically significant and range from $7.73 \%$ in the first year to $4.69 \%$ in the fifth year. The average benchmark-adjusted return in the sixth year after portfolio formation (not tabulated) is, however, no longer statistically significant, indicating that the information about future returns contained in EM at portfolio formation becomes weak after this time.

Examining the EM characteristics of low- and high-EM firms provides an explanation for the long-lasting outperformance. Firms classified as low-EM firms tend to maintain their low EM characteristic over a long time. In particular, the average EM for low-EM firms is 3.4 at portfolio formation. In the year before and after portfolio formation, the average characteristic is 4.3 and 4.5, respectively, and then slowly but steadily grows to an average EM of 5.5 in the fifth year. Similarly, high-EM firms tend to stay high-EM firms, though they exhibit a quicker reversion to the mean than low-EM firms. The average EM for high-EM firms is 13.3 in the year before and 23.3 at portfolio formation, which is then continuously reduced to 9.9 in the fifth year. The flattening of the EM dispersion finally turns the return difference between low- and high-EM firms insignificant in the sixth year after portfolio formation. Nevertheless, the EM value effect exists for holding periods up to 5 years, making the EM an exceptionally persistent strategy for investors.

\section{Further Robustness Tests}

In this section, we check the robustness of our inferences on the EM in international markets. We examine the sensitivity of the results presented above in split-sample cross-sectional regressions to dissect the return predictive ability of EM in different subsamples and subperiods. We further ask whether the different accounting standards followed by the sample firms are influential in the results observed in this study. Finally, we analyze the extent to which the EM value premium is explained by the $q$-theory factor model of Chen, Novy-Marx, and Zhang (2010).

January Seasonal Effect. Keim (1983) highlights the seasonal impact of January on the size effect. Loughran (1997) argues that the BM value premium is driven by a January seasonal pattern as well. To address these concerns in the case of the EM, we estimate international cross-sectional regressions in an analogous manner to Table 3, removing all January returns. We find that the return predictive ability of EM remains robust in terms of economic and statistical significance.

Robustness across Time. We estimate international split-sample crosssectional regressions of monthly stock returns on the EM and the common benchmark variables ME, BM, and MOM for two different subperiods. The early 
subperiod covers July 1981 to June 1995, while the later subperiod covers July 1995 to June 2010. The obtained results confirm our findings from Table 3. The coefficient on EM is highly significant in all subperiods. Thus, the EM proves to be a robust average-return predictor across time.

Impact of Accounting Standards Followed. To examine whether firms' underlying accounting rules are influential in the results observed in this paper, we estimate cross-sectional regressions separately for firms following local standards, international standards, and U.S. generally accepted accounting principles (GAAP) using the classification guidelines provided in Daske, Hail, Leuz, and Verdi (2013). Estimating separate regressions for different accounting groups allows difference-of-means tests of whether the relations between average returns and a variable differ across accounting groups. The dependent variable is the monthly stock return for a firm, and the independent variables are EM, ME, $\mathrm{BM}$, and MOM. The results confirm our prior findings in this paper. The return predictability of EM is significantly present in every accounting group. Furthermore, the return predictive power of the EM is independent of firms' underlying accounting rules since none of the difference-of-means tests for the average EM slopes is statistically significant between the three groups. Thus, we infer that there is no significant influence of the accounting regime on the EM.

Relation to the q-Theory Factor Model. Loughran and Wellman (2011) establish that the U.S. EM value premium is robust to the controls of the $q$-theory factor model. To test this relation outside the United States, we carefully construct the investment and profitability factors following Chen et al. (2010). Without going into all the details, we confirm the findings of Loughran and Wellman. Regressing the international EMD return on the $q$-theory factors generates a high and significant alpha estimate of $1.00 \%$ per month $(t$-statistic $=6.65)$ with a low adjusted $R^{2}$ value of 0.20 in analogy to the setting of Panel A of Table 5. Similarly, we find at the country level that 24 EM value premiums cannot be explained by their exposures to the country-specific $q$-theory factors, as indicated by positive and significant alpha estimates in analogy to the setting of Panel B.

\section{Conclusions}

In this paper, we comprehensively extend the Loughran and Wellman (2011) U.S. evidence on the EM to international markets using a large sample of 40 individual non-U.S. countries during the time period 1981 to 2010.

As in the United States, we find that the EM is an economically meaningful and statistically significant predictor of the cross section of international returns. The return predictive ability is similarly existent in developed markets and emerging markets and robust across small firms and large firms, after controlling for previously documented determinants of the cross section like size, BM value, and momentum.

Furthermore, we confirm the existence of a sizeable EM value premium in international markets. An internationally diversified portfolio of low-EM firms outperforms a portfolio of high-EM firms by about $1 \%$ per month. The strong performance of the EM strategy comes from both ends, since firms with low-EM 
characteristics produce high subsequent excess returns in general, whereas firms with high-EM characteristics produce in general low subsequent excess returns that are close to 0 .

The EM value premium is strongly pervasive, as it appears in the majority of countries and cannot be explained by either common return factors of existing asset pricing models or the comovement with the respective U.S. premium. Though the EM value premium shares commonalities with BM value and momentum strategies by loading on the respective return factors, the EM strategy generates positive and significant 4-factor alphas in the aggregate international markets and in more than half of the 40 investigated countries. As low-EM firms and high-EM firms tend to maintain their EM characteristics over a long time, the abnormal performance of the EM value premium persists for up to 5 years after portfolio formation, making it a promising strategy for investors.

Since our findings are out of sample relative to the previous U.S. evidence of Loughran and Wellman (2011), the implication is that the EM value premium is not just sample specific but rather a global phenomenon around the world.

Our results are robust with respect to varying methodological approaches, and we draw similar inferences from analyses at different aggregation levels based on cross-country international markets, developed and emerging markets, and individual countries. Furthermore, controlling for seasonality effects, subperiods, different accounting standards followed by the sample firms, and the $q$-theory factors in additional robustness tests does not change the paper's general findings.

Comparing our results to those in Loughran and Wellman (2011) reveals that the EM exhibits an even stronger effect on subsequent returns in international markets than in the United States. Loughran and Wellman interpret the EM as a proxy for the discount rate. Regardless of whether the documented EM-return relation is the result of market inefficiencies or rational pricing, finding significant EM value premiums in such a large number of individual countries, drawn from developed and emerging markets, makes it unlikely that sample selection can explain the EM value effect. A further analysis of the economic fundamentals driving the EM value premium is beyond the scope of this paper but promises to be an interesting avenue for future research.

\section{Appendix. Definitions of the Datastream and Worldscope Data}

Accounting Standards Followed. This variable holds the firm's underlying accounting rules (item WC07536).

Book-to-Market Equity. This is book value of common equity for the fiscal year ending in the preceding calendar year divided by market equity at the end of that year (item WC03501/WC08001).

EBITDA. This is earnings before interest, taxes, and depreciation (item WC18198).

Enterprise Value. This is market value of common equity plus total debt plus market value of preferred equity minus cash and short-term investments (item WC18100).

Market Equity. This is the stock price multiplied by the number of shares outstanding (item MV). 


\section{References}

Ang, A.; R. J. Hodrick; Y. Xing; and X. Zhang. "High Idiosyncratic Volatility and Low Returns: International and Further U.S. Evidence." Journal of Financial Economics, 91 (2009), 1-23.

Asparouhova, E.; H. Bessembinder; and I. Kalcheva. "Liquidity Biases in Asset Pricing Tests." Journal of Financial Economics, 96 (2010), 215-237.

Asparouhova, E.; H. Bessembinder; and I. Kalcheva. "Noisy Prices and Inference Regarding Returns." Journal of Finance, 68 (2013), 665-714.

Carhart, M. M. "On Persistence in Mutual Fund Performance.” Journal of Finance, 52 (1997), 57-82.

Chen, L.; R. Novy-Marx; and L. Zhang. "An Alternative Three-Factor Model." Working Paper, Washington University in St. Louis (2010).

Chordia, T., and L. Shivakumar. "Earnings and Price Momentum." Journal of Financial Economics, 80 (2006), 627-656.

Chui, A. C. W.; S. Titman; and K. C. J. Wei. "Individualism and Momentum Around the World." Journal of Finance, 65 (2010), 361-392.

Daniel, K., and S. Titman. "Evidence on the Characteristics of Cross Sectional Variation in Stock Returns." Journal of Finance, 52 (1997), 1-33.

Daske, H.; L. Hail; C. Leuz; and R. Verdi. "Adopting a Label: Heterogeneity in the Economic Consequences of IFRS Adoptions.” Journal of Accounting Research, 51 (2013), 495-547.

Davis, J. L.; E. F. Fama; and K. R. French. "Characteristics, Covariances, and Average Returns: 1929 to 1997." Journal of Finance, 55 (2000), 389-406.

Eun, C. S., and J. Lee. "Mean-Variance Convergence Around the World." Journal of Banking \& Finance, 34 (2010), 856-870.

Fama, E. F., and K. R. French. "The Cross-Section of Expected Stock Returns.” Journal of Finance, 47 (1992), 427-465.

Fama, E. F., and K. R. French. "Common Risk Factors in the Returns on Stocks and Bonds." Journal of Financial Economics, 33 (1993), 3-56.

Fama, E. F., and K. R. French. "Value versus Growth: The International Evidence." Journal of Finance, 53 (1998), 1975-1999.

Fama, E. F., and K. R. French. "The Value Premium and the CAPM.” Journal of Finance, 61 (2006), 2163-2185.

Fama, E. F., and K. R. French. "Dissecting Anomalies.” Journal of Finance, 63 (2008), 1653-1678.

Fama, E. F., and K. R. French. "Size, Value, and Momentum in International Stock Returns." Journal of Financial Economics, 105 (2012), 457-472.

Fama, E. F., and J. D. MacBeth. "Risk, Return, and Equilibrium: Empirical Tests.” Journal of Political Economy, 81 (1973), 607-636.

Griffin, J. M. "Are the Fama and French Factors Global or Country Specific?" Review of Financial Studies, 15 (2002), 783-803.

Griffin, J. M.; X. Ji; and J. S. Martin. "Momentum Investing and Business Cycle Risk: Evidence from Pole to Pole." Journal of Finance, 58 (2003), 2515-2547.

Harvey, C. R. "Predictable Risk and Returns in Emerging Markets." Review of Financial Studies, 8 (1995), 773-816.

Heston, S. L.; K. G. Rouwenhorst; and R. E. Wessels. "The Structure of International Stock Returns and the Integration of Capital Markets.” Journal of Empirical Finance, 2 (1995), 173-197.

Hong, D.; C. M. C. Lee; and B. Swaminathan. "Earnings Momentum in International Markets." Working Paper, Singapore Management University (2003).

Hong, H.; T. Lim; and J. Stein. "Bad News Travels Slowly: Size, Analyst Coverage and the Profitability of Momentum Strategies.” Journal of Finance, 55 (2000), 265-295.

Horowitz, J. L.; T. Loughran; and N. E. Savin. "The Disappearing Size Effect." Research in Economics, 54 (2000), 83-100.

Ince, O. S., and R. B. Porter. "Individual Equity Return Data from Thomson Datastream: Handle with Care!" Journal of Financial Research, 29 (2006), 463-479.

Jegadeesh, N. "Evidence of Predictable Behavior of Security Returns.” Journal of Finance, 45 (1990), $881-898$.

Keim, D. B. "Size-Related Anomalies and Stock Return Seasonality: Further Empirical Evidence." Journal of Financial Economics, 12 (1983), 13-32.

Lo, A. W., and A. C. MacKinlay. "Data-Snooping Biases in Tests of Financial Asset Pricing Models." Review of Financial Studies, 3 (1990), 431-468.

Loughran, T. "Book-to-Market Across Firm Size, Exchange, and Seasonality: Is There an Effect?" Journal of Financial and Quantitative Analysis, 32 (1997), 249-268.

Loughran, T., and J. W. Wellman. "New Evidence on the Relation between the Enterprise Multiple and Average Stock Returns.” Journal of Financial and Quantitative Analysis, 46 (2011), 1629-1650. 
Newey, W. K., and K. D. West. "A Simple, Positive Semi-Definite, Heteroskedasticity and Autocorrelation Consistent Covariance Matrix.” Econometrica, 55 (1987), 703-708.

Rouwenhorst, K. G. "International Momentum Strategies.” Journal of Finance, 53 (1998), 267-284.

Rouwenhorst, K. G. "Local Return Factors and Turnover in Emerging Stock Markets." Journal of Finance, 54 (1999), 1439-1464.

Titman, S.; K. C. J. Wei; and F. Xie. "Capital Investments and Stock Returns.” Journal of Financial and Quantitative Analysis, 39 (2004), 677-700.

Titman, S.; K. C. J. Wei; and F. Xie. "Capital Investments and Stock Returns in Japan.” International Review of Finance, 9 (2009), 111-131. 